\title{
Radical youth communities in the virtual space
}

\section{Comunidades radicales de juventud en el espacio virtual}

\author{
IVANOV, Andrey Valeryevich†'*' \& SIRYUKOVA, Yana Alexeevna" \\ 'Candidate of Historical Sciences, associate professor of the Department of Conflict Management of the Institute of Social and \\ Philosophical Sciences and Mass Communications, Kazan (Volga state) Federal University, Russia.
}

\begin{abstract}
"Senior Lecturer of Department of Conflict Resolution Studies Institute of Social and Philosophical Sciences and Mass Communications, Kazan (Volga state) Federal University, Russia.
\end{abstract}

ID $1^{\text {st }}$ Author: Andrey Valeryevich, Ivanov / ORC ID: 0000-0002-6491-6267

ID $1^{\text {st }}$ Co-author: Yana Alexeevna, Siryukova / ORC ID: 0000-0002-0265-3588

DOI: $10.35429 /$ EJM.2021.26.12.39.48

Received: January 25, 2021; Accepted: June 30, 2021

\begin{abstract}
Virtual space (Internet space) is a universal cross-border environment in which a considerable number of topics and concepts of destructive orientation among young people circulate and are popularized generated. The Internet has become one of the most important and effective means of communication in the modern world. Virtual communities usually become actors in information as well as political processes. The article deals with youth subcultural communications in radical Internet communities. First of all, these communications are based on concepts and patterns that arise in connection with the establishment as well as the implementation of xenophobic views and teachings. Political, ideological, racial, national, or religious hatred against any social, religious, or ethnic group, the promotion of homicidal scenarios, or even auto aggression becomes a pivotal key in consolidating users in such destructive communities. Overall, it can be concluded that the development of adverse opinions of communicative behavior relevant to other participants in virtual communities may well result in an enhanced sense of collective identity.
\end{abstract}

Virtual Space, Youth, Conflicts, Youth Subcultures, Destructive Communities

\begin{abstract}
Resumen
El espacio virtual (espacio de Internet) es un entorno universal transfronterizo en el que circulan y se popularizan un número considerable de temas y conceptos de orientación destructiva entre los jóvenes. Internet se ha convertido en uno de los medios de comunicación más importantes y eficaces del mundo moderno. Las comunidades virtuales suelen convertirse en actores tanto de la información como de los procesos políticos. El artículo trata sobre las comunicaciones subculturales de los jóvenes en las comunidades radicales de Internet. En primer lugar, estas comunicaciones se basan en conceptos y patrones que surgen en relación con el establecimiento y la implementación de visiones y enseñanzas xenófobas. El odio político, ideológico, racial, nacional o religioso contra cualquier grupo social, religioso o étnico, la promoción de escenarios homicidas o incluso la autoagresión se convierte en una clave fundamental para consolidar a los usuarios en comunidades $\tan$ destructivas. En general, se puede concluir que el desarrollo de opiniones adversas de comportamiento comunicativo relevantes para otros participantes en comunidades virtuales bien puede resultar en un mayor sentido de identidad colectiva.
\end{abstract}

Espacio Virtual, Juventud, Conflictos, Subculturas Juveniles, Comunidades Destructivas

Citation: IVANOV, Andrey Valeryevich \& SIRYUKOVA, Yana Alexeevna. Radical youth communities in the virtual space. ECORFAN Journal-Mexico. 2021. 12-26:39-48.

\footnotetext{
* Correspondence to Author (Email: andrey.ivanov77@yahoo.com)

$\dagger$ Researcher contributing first author.
} 


\section{Introduction}

The concept of "community" is the basic one for this study. In the social science of the XIX-XXI centuries, the concept of community has undergone an evolution. At first, "community" was understood as territorial and geographical proximity, kinship relations. Gradually, "community" became understood as a structural community of individuals communicating within social networks.

The term "community" was a key one in M. Weber, E. Durkheim, and K. Marx. However, sociologists and anthropologists had different theoretical models of community. They put different meanings into the definition of community. Often in theories, the concept of "community" was associated with social rituals. This approach was observed in the works of Durkheim and Tennis (Tonnies, 1965; Abdi, \& Basarati, 2018; Gonsalves et al., 2020).

The Russian sociological encyclopedia gives the following definition: "Community-an Association of individuals who have common goals" (The Russian sociological encyclopedia. Moscow: Norma-Infra, 1998). We must admit that the concept of "community" is one of the vaguest sociological terms, which is interpreted differently in scientific works. The use of this definition is possible if the study specifies explicitly what is meant by it.

The formation of the "information economy" and the development of telecommunications networks requires a reevaluation of the role of communities as primary units in the social hierarchy of society. From sociology, the term "communication" is considered as the organization of socio-cultural and economic interaction of people, groups, organizations, enterprises, States, and regions using information tools (Bondarenko, 2004).

In the 80 s of the $\mathrm{XX}$ century, the first works of Western researchers on the problems of virtual network space appeared. S. Hilts and M. Taroff were among the first to note the fact of the formation of a new social structure of society, mediated by computer technologies (Hiltz \& Turoff, 1993, LaPadula et al., 2020).
The operation of virtual network communities in a social and technical environment or cyberspace. This environment has tremendous differences from the everyday physical environment. When considering the social structure of virtual network communities, it is necessary to describe the very environment in which social interactions occur.

According to social anthropologist Brian Pfaffenberger, virtuality is not a "new reality", but a part of everyday human life. Virtuality is social, so it is correct to use the term "social virtuality" (Pfaffenberger, 1992; Ventura Ccasa, 2021).

Communications of participants of thematic youth groups in the op-line and offline space have both points of divergence and points of contact. It is the virtual space that expands the possibilities of communication, leisure, mobility, and accessibility of various types of thematic youth groups. On the other hand, attribution of belonging to the youth (primarily destructive) subculture in the offline space is optional, and important is the problem of identifying "friend-foe,", identity and marking "correct and incorrect" information (concepts) in the network space by participants. An essential part of our research will consider transforming the transition of destructive youthsubcultural from the real to the virtual space (Ivanov, 2017; Farzadnia, \& Giles, 2015; Nalani et al., 2021).

\section{Literature review}

Different writers have tended to the subject of this article from alternate points of view. As per Preece (in Kardaras 2003), a virtual local area comprises of:

People who collaborate socially as they endeavor to fulfill their own necessities or perform socialroles, like driving or directing.

A common perspective, like an interest, need, data trade or administration that gives motivation to the local area.

- Policies as implied suspicions, conventions, decides and laws that guide individuals' communications.

Computer frameworks to help and intercede social cooperation and encourage a feeling of harmony. 
Gonsalves et al., (2020) characterizes virtual networks as gatherings of individuals connected not by geology but rather by their support in PC organizations. They share a large number of the qualities of individuals in normal networks, yet have no vis-à-vis contact, are not limited by the requirements of time or spot, and use PCs to speak with each other. The term 'local area' is utilized in a more broad sense than in sociological examination where sharing convictions or a sensation of having a place with a similar local area is viewed as fundamental for review a gathering of people as a local area. Kyrnin (2003) utilizes the WWWebster Dictionary meaning of local area to characterize the idea 'virtual local area': the primary necessity for a local area is that individuals share regular interests; consequently, any individual who visits a specific Web webpage is important for the local area of that Web website. This is an expansive definition and does exclude the significant necessity of standard guests who communicate with each other and partake in data sharing. Armstrong and Hagel (in Kardaras 2003) contend that there are four local area types that reflect purchaser needs:

Communities of exchanges encourage the requirement for purchasing and selling of items and administrations or trade of data. The individuals from the local area are urged to speak with one another to take part in exchange. The 'Virtual Vineyards', for instance, is a local area that permits members to purchase and sell wine from little grape plantations.

Communities of interest unite individuals with a typical distraction about a point, for instance sports, vehicles, food and workmanship. These people group include a more significant level of relational correspondence than the networks of exchange. Such people group can be 'vengeance' Websites, like McSpotlight, which gives pessimistic data about McDonalds, and The Living Wages, which gives adverse data about Nike (Nalani et al., 2021).

Different people group of interest, for example, the email discussion for Mercedes Benz fans (Easley n.d.) give generally certain data about items and, if pessimistic data is given, the point is to improve the items or administration.
Tosun (2012) states that the principle utilizes for Facebook incorporate keeping up long$\neg$-distance connections, game playing/amusement, photograph $\neg$-related exercises, putting together get-togethers, latent perceptions, building up new fellowships and starting/ending close connections (Tosun 2012:1512; Ventura Ccasa, 2021). Tosun contends that communicating one's self on the Internet is an approach to frame cozy associations with individuals that are met through interpersonal interaction website and that clients use Facebook as a social substitutes to make disconnected connections and reinforce existing connections (Tosun 2012:1512). Subsequent to examining the information, Tosun inferred that Facebook is a support for those with issues articulating their contemplations and sentiments face to face and is utilized as a substitute for building up connections (Tosun 2012:1517; Gonsalves et al., 2020). The thoughts inside the Tosun article seeing Facebook as a social substitute to make connections upholds the hypothesis inside this exploration that more mingling is happening in the online circle. By making an online personality, which is utilized to make these fellowships with others, the client is taking part in the particular cycle of character arrangement talked about in the previously mentioned articles. At the point when these connections are then taken into a disconnected situation, the client expects the part of beneficiary online personality and plays out the character that their partner has come to know, acknowledge and comprehend.

Acquisti and Gross (2006) contend that there is frequently a distinction between understudies' longing to secure protection and their practices, a topic that is likewise investigated in Stutzman's (2006) overview of Facebook clients and Barnes' (2006) portrayal of the "protection Catch 22" that happens when teenagers don't know about the public idea of the Internet. In breaking down trust on interpersonal organization locales, Dwyer, Hiltz, and Passerini (2007) contended that trust and use objectives may influence what individuals will share-Facebook clients communicated more noteworthy trust in Facebook than MySpace clients did in MySpace and along these lines were more able to share data on the site. In another examination inspecting security issues and SNSs, Jagatic, Johnson, Jakobsson, and Menczer (2007) utilized uninhibitedly open profile information from SNSs to make a "phishing" plot that seemed to begin from a companion on the organization; their objectives were significantly more prone to part with data to this "companion" than to an apparent outsider.

IVANOV, Andrey Valeryevich \& SIRYUKOVA, Yana Alexeevna. Radical youth communities in the virtual space. ECORFAN Journal-Mexico. 2021 
Study information offer a more idealistic point of view on the issue, recommending that youngsters know about potential security dangers on the web and that many are proactive about finding a way ways to limit certain expected dangers. Seat tracked down that $55 \%$ of online youngsters have profiles, $66 \%$ of whom report that their profile isn't noticeable to all Internet clients (Lenhart and Madden, 2007; LaPadula et $a l ., 2020)$. Of the youngsters with totally open profiles, $46 \%$ revealed including probably some bogus data.

\section{Methods}

The transition to the information society has significantly accelerated the pace of social processes. The world computer network has destroyed the space-time boundaries and allowed an almost uncontrolled exchange of content and communication actions. In this situation, it is quite challenging to localize youth extremism.

The majority of Internet users are representatives of the youth environment. Young people are hyperactive users of social networks who get most of their information from the Internet. The Internet surrounds and affects them everywhere: you can access the virtual network using various gadgets and devices. A serious circumstance is a fact that the worldview of teenagers and young people is still at the stage of formation and development. On the other hand, we must admit that one part of people lives in the real world, and the other considers the virtual world to be the real world. This parallelism between the real and the virtual is seen in the generational conflict between young users of the Internet space and the generation that did not find this information and technology boom and such virtual vryamepravlenie at least perceive warily. It should be taken into account that the Internet, with its massive range of opinions and views, sometimes having an unethical or destructive character, can pose a real danger. This applies primarily to those portals and forums that are created to promote ideas of terrorism and extremism with racial background. Virtual people group comprise of individuals with a common perspective who impart and share data by methods for electronic organizations. Virtual people group are essential for the data age and the data economy. In view of the straightforwardness and speed with which data can be dispersed through virtual networks, they present the two chances and dangers to organizations.
The ramifications for organizations are that they should misuse the chances by making virtual networks of training and client networks. In spite of the fact that organizations can't handle data dispersal in online networks, they can limit the dangers to their standing by ensuring they realize the thing is being said about their items and administrations, and by partaking in online networks. From the different meanings of virtual networks, unmistakably correspondence, and subsequently sharing and 'exchanging' of data, is the general purpose of being essential for a virtual local area. Various sorts of virtual networks can be recognized, in view of on individuals that make up the networks, or the reason for which the local area is made.

The idea of informal organization, first begat in 1954 by J. A. Barnes in, has been in a fieldof investigation of current social science, humanities, geology, social brain research, authoritative examinations and software engineering for most recent couple of many years (Barnes, 1954:39; LaPadula et al., 2020). The idea of interpersonal organization and informal community examination have been produced for some areas, for example, corporate association organizations (law association), researcher or different callings joint effort organizations, family organizations, companionship organization of understudies, organization chief organizations, sexual contact organizations, client organizations, work market, general wellbeing, brain science, and so forth As of late, it turns into a piece of the new control of science called computational sociology (Lazer et al., 2009 : 721). With the development of the Internet and the expanding prominence of social and communitarian registering, as of late usually called social figuring, interpersonal organizations have arisen as a huge and promising field of study inside software engineering. Social figuring includes such exercises as gathering, removing, getting to, preparing, registering, and envisioning of all sort of friendly data (King, 2010:482; Nalani et al., 2021).

An informal communication administration (SNS) is an Internet-based stage utilized in building and creating social relations among individuals. It gives implies by which clients can interface online with individuals of comparative interests, regardless of whether it be for heartfelt or social reason. It permits clients to share messages, texting, online remarks, wikis, computerized photographs and recordings, and post blog passages. 
It additionally offers individuals with handicaps an opportunity to spread the word about their musings and suppositions in a virtual climate. Informal communities serve double parts as both the providers and the customers of substance. They give the client a decision of who can see their profile. A profile is created from answers to questions, like age, area, interests, and so forth A few locales permit clients to transfer pictures, add interactive media content or change the look and feel of the profile, post web journals, remark on postings, accumulate and share rundown of contacts. To secure client protection, informal communities regularly have controls that permit clients to pick who can see their profile, reach them, add them to their rundown of contacts, etc (Matthew et al., 2019: 126; Ventura Ccasa, 2021). Informal organization destinations additionally give rich wellsprings of naturalistic social information. Profile and linkage information from SNSs can be accumulated either using robotized assortment procedures or through datasets gave straightforwardly from the organization, empowering network investigation analysts to investigate enormous scope examples of friending, utilization, and other obvious pointers (Hogan, in press), and proceeding with an examination pattern that began with assessments of online journals and different sites. For example, Golder, Wilkinson, and Huberman (2007) analyzed an anonymized dataset comprising of 362 million messages traded by more than 4,000,000 Facebook clients for knowledge into Friending and informing exercises. Lampe, Ellison, and Steinfield (2007) investigated the connection between profile components and number of Facebook companions, finding that profile handle that decrease exchange costs and are harder to adulterate are well on the way to be related with bigger number of kinship joins. These sorts of information additionally loan themselves well to examination through network perception (Adamic, Buyukkokten, and Adar, 2003; Heer and boyd, 2005; Paolillo and Wright, 2005; LaPadula et al., 2020).

Social networks and the blogosphere are the same manifestation of a mass character, the same psychology of the street crowd. Here, however, the coverage is significantly more significant, and the rate of dissemination of toxic information is much higher.
It is necessary to take into account the stereotype of the behavior of the majority of users who see a bright, catchy title associated, for example, with an ethnic crime, click on the button "repost", "retweet", or "share". In other words, the process of spreading rumors, and here we can say extremist content that is brightly decorated, turns into an uncontrolled phenomenon.

The phenomenon of virtual sociality makes it possible to invent your own identity: ethnic, gender, material, and legal, to create a selfpresentation of your political views. It is the realization of what individuals think of themselves, not what they are in reality. Virtual masks-avatars replace the physics of the face, nicknames symbolize the inner content that the subject of the network attributes to itself, the inner world is filled with the help of network political exchange of information. Identity can be continuously updated and changed in the virtual space. Age, gender, social status, and political beliefs that cannot be transformed by an individual every day in real space are constantly being constructed in virtual space. The consciousness of the average user of social networks has a clip character, which does not want to tire itself with long texts and tries to form ideological attitudes through a bright video series, slogans, demotivators, and memes that are emotionally charged and through constant reference to them create stable stereotypes. There is a fundamental social problem, which is that a generation has grown up that can no longer imagine their life without virtual space, constant Internet surfing, and social networking. In these conditions, new virtual leaders appear who create network policies and force real actions (Kiselev, 2007; Ventura Ccasa, 2021).

The Internet space allows you to express yourself in various role-playing opportunities to determine your own path of development. As practice shows, the violation or destruction of real social ties leads teenagers to leave the world of virtual communication. The ability to quickly mobilize the Internet community and a significant number of participants in communication and bring the confrontation to the public view of virtual conflicts that entail certain evaluative opinions increase the acuteness of the communication itself and its consequences.

In the interpretation of anthropologist Marshall McLuhan, media is understood as extensions of the human sense organs: sight, hearing, and touch. Social networks are a projection of human organs.

IVANOV, Andrey Valeryevich \& SIRYUKOVA, Yana Alexeevna. Radical youth communities in the virtual space. ECORFAN Journal-Mexico. 2021 
The network as a media is an extension of the human sensory world. In other words, online sociality is a modified offline sociality (McLuhan, 1964). The new virtual sociopathies are just a network extension of real-world sociopathies. Questions with the definition of ethnic identity and identification of "pure races" usually end in virtual sociopathy, where hostility towards "Strangers", who are identified primarily with migrants, begins to manifest itself (Ivanov, 2017; Nalani et al., 2021).

Overall, this study seeks to analyze radical youth communities in the virtual space. Hence, to fulfil that aim, a descriptive method is utilized to gather and analyze needed data. Besides, the authors attempt to analyze General trends in the Internet to expand and update the relevant data.

Online sociality should be considered as a different kind of sociality, where the possibility of translating these relationships from the network into real everyday life is not excluded. The connections existing on the Internet can be grouped from various perspectives and dependent on various qualities (Figure 7):

Active subject that is answerable for formation of new connections (client, framework, client and framework).

Awareness of the clients that they are engaged with connections.

Mutuality of the association between clients (awry, balanced, reflexive).

General relationship sources (outside or virtual world).

Data type utilized by the framework for relationship creation (direct cooperation, normal movement, client profiles, none if the relationship is made by client).

Nature of connections (proficient, family, kinship, colleague, normal interest, and so forth).

Visibility of connections for the clients (completely or part of the way obvious, imperceptible).

Directness of relationship grounds (immediate, semi-immediate, backhanded) (Beyene, 2008).

\section{Results and discussion}

The Internet is changing the manner in which we work, unwind, communicate ... it is changing the way we live. The virtual local area is one of the better approaches for collaboration that has been made conceivable by the Internet. Catch, stockpiling, dispersal and age of (new) data happen rapidly and viably in virtual networks on the grounds that the Internet empowers simultaneous and nonconcurrent correspondence in an unexpected way. Virtual people group are relied upon to develop into a deliberately significant plan of action. They along these lines have certain ramifications for organizations. From one perspective, there are advantages and openings: organizations can improve client support and client relations and all the more effectively spread data and virtual networks can likewise go about as discussions for information sharing, learning and coordinated effort. Then again, virtual networks can be utilized to disperse negative data about an organization that can hurt its standing, prompting loss of clients. The ramifications is that organizations need to observe virtual networks and decide how they can utilize virtual networks for their potential benefit just as limit the dangers presented by virtual networks (Buhrmann, 2003; Gonsalves et al., 2020). Albeit the investigation of virtual networks is in its earliest stages, it has effectively pulled in light of a legitimate concern for specialists from various controls and points of view, including PC interceded correspondence (Herring, 2002), ethnography (Rice-Levy, 1994; Ward, 1999; William, 2000), social organization examination (Wellman and Gulia, 1999),social financial matters (Kollock, 19991, humanism (Fox and Roberts, 19991, and data science (Burnett, Besant, and Chatman, 2001; Romm, Pliskin, and Clarke, 1997; Nalani et al., 2021). The issues associated with considering virtual networks are not insignificant; issues incorporate the fittingness of the strategies utilized (Ward, 1999), moral issues associated with such investigations (Menon, 1998), and the possibly negative impacts on the virtual networks (Smith and Kollock, 1999; LaPadula et al., 2020). All things considered, virtual networks give freedoms to scientists to examine the conduct, or discernments, of scattered networks continuously, just as over the long run, something that was troublesome, if certainly feasible, before the coming of the Internet and the WorldWide Web. Investigation of virtual networks may likewise offer bits of knowledge into the discernments and activities of actual networks through investigations of their virtual partners. 
The utilization of arranged virtual networks to help learning in advanced education has been looked into by Wachter, Gupta, and Quaddus (2000).

A representative of radical groups is usually a young man of $16-28$ years old, who is interested in neo-pagan projects and runic writing. More often a student of technical or natural science fields than of Humanities. Quite often, you can see the evolution from moderate radical groups in social networks to openly rightwing ones with an outright Nazi program. Ridings et al. (2002: 273) offer an extensive meaning of the term (virtual local area) that accepts the credits examined above: (gatherings of individuals with normal interests and practices that convey routinely and for some length in a coordinated manner over the Internet through a typical area or component.) This definition is utilized in this examination. Instances of virtual networks are announcement sheets where similar individuals come, consistently, to talk about normal interests, for example, battling bosom malignancy, gathering old-fashioned containers, or the issues of claiming a Saber boat. Since people group enrollment has not been unequivocally characterized in the writing and since the normal use of the term (enrollment) manages individuals who don't effectively add to the local area yet at the same time partake, even quietly, in its exercises, this examination characterizes a part as any individual who take an interest the virtual revolutionary organization local area is more appealing to the client. Moreover, it is United and stable in the virtual space. Social characteristics of communities, with their racial ideologies and mythologems, to which users of this group are loyal, are a marker for determining and graduating participants according to the principle of "Own" and "Alien". Constant communication practices create a collective "We", that is, a shared identity. In the virtual space, it is possible to create collective identities that are both constructive and destructive (Ventura Ccasa, 2021).

The collective identity of a radical in virtual space can be formed in three stages.

Initially, during the initial socialization, the newcomer is influenced by the collective identity of the group, but the individual identity also affects the collective one.
The second stage for an actor is participation in the formation of a collective identity.

At the third stage, the actor, in communication with representatives of other groups, translates the collective identity, and only then the individual identity. Further, it is possible to switch to more radical groups that promote power actions.

Collective identity is not limited to the factors of psychoemotional attachment to the community on the part of the user but also includes cognitive and evaluative moments. So, when talking about collective identity, it is necessary to emphasize the commitment to group-wide social values and solidarity in defending common ideals. Group identity in virtual communities is an essential mechanism for preventing external threats and reducing intra-group conflicts. Only identifying yourself with other members of the community creates a sense of belonging to the group, and if there are conflict situations, it makes you rise above your interests.

\section{Conclusions}

Over the course of the study, it was tried to analyze youth subcultural communications in radical Internet communities. As mentioned before, these communications are on the basis of concepts and patterns that arise in connection with the establishment as well as the implementation of xenophobic views and teachings. A descriptive method and data-gathering method over the Internet were utilized to complete the aim of the study. Based on the results acquire, it can be concluding that the formation of negative attitudes of communicative behavior relative to other participants in virtual communities leads to an increased sense of group identity. This is typical for representatives of radical virtual network communities.

On the other hand, the system problem was the "simulation" of social reality, the creation of a "parallel reality" that Zh. Baudrillard (Jean, 1981). Many social phenomena of this object world, passing from objective reality to virtual, mutate, that is, acquire new features and features.

An analysis of General trends in the Internet in recent years shows that social networks have become the leading virtual platform for promoting radicalism, and there are a number of reasons for this.

IVANOV, Andrey Valeryevich \& SIRYUKOVA, Yana Alexeevna. Radical youth communities in the virtual space. ECORFAN Journal-Mexico. 2021 
First, a huge human resource is initially concentrated here.

Secondly, creating and promoting a theme group requires significantly less time and financial expenses than for promoting an individual site.

Third, the loyal policy of the administration of some social networks to the content posted and promoted.

The conflictogenicity of virtual space is most clearly manifested in social networks, due to the fact that they are a kind of projection of real communications, as well as socio-economic and political events in society. The General availability of social networks contributes to the mass Association of people in whole communities, which form the unity of their ideas and opinions on various grounds, which may not always be constructive and legitimate. Such forms of collectivism create relevant platforms for the implementation of virtual conflict. The mass of the Internet audience is attractive for administrators of certain banned or most aggressive communities, not only by the possibility of attracting new like-minded people but also by searching for "enemies of the community".

\section{Acknowledgements}

The work is performed by the Russian Government Program of Competitive Growth of Kazan Federal University.

\section{References}

Abdi, R., \& Basarati, A. (2018). Legitimation in discourse and communication revisited: A Critical view towards legitimizing identities in communication. International Journal of Society, Culture \& Language, 6(1), 86-100.

Acquisti, A., \& Gross, R. (2006, June). Imagined communities: Awareness, information sharing, and privacy on the Facebook. In International workshop on privacy enhancing technologies (pp. 36-58). Springer, Berlin, Heidelberg.

Barnes, J. A. (1954). Class and committees in a Norwegian island parish. Human relations, 7(1), 39-58.

Barnes, S. B. (2006). A privacy paradox: Social networking in the United States. First Monday.
Beyene, Y., Faloutsos, M., Chau, D. H., \& Faloutsos, C. (2008, April). The eBay Graph: How do online auction users interact? In IEEE INFOCOM Workshops 2008 (pp. 1-6). IEEE.

Bondarenko, S.V. (2004). Social structure of virtual network communities. Rostov-on-don, 1832.

Buhrmann, C. H. (2019). Virtual communities: implications for companies, Coris Capital Ltd Post Graduate Diploma in Information Management Rand Afrikaans University. south African journal of information management, 4(4).

Burnett, G., Besant, M., Chatman, E.A. (2001). Small worlds: Normative behavior in virtual communities and feminist bookselling. Journal of the American Society for Information Science, 52.

Dwyer, C., Hiltz, S., \& Passerini, K. (2007). Trust and privacy concern within social networking sites: A comparison of Facebook and MySpace. AMCIS 2007 proceedings, 339.from http://csis.pace.edu/ dwyer/research/ DwyerAMCIS2007.pdf.

EASLEY, R.W. n.d. Virtual communities ... the power of word-of-mouth transmission via the Internet. [Online]. 2003. Available WWW: http://www.arraydev.com/commerce/jim/020304.htm.

Farzadnia, S., \& Giles, H. (2015). Patient-provider interaction: a communication accommodation theory perspective. International Journal of Society, Culture \& Language, 3(2), 17-34.

Gonsalves, K., Foth, M., Caldwell, G., \& Jenek, W. (2020). Radical Placemaking: Immersive, Experiential and Activist Approaches for Marginalised Communities. Connections: Exploring Heritage, Architecture, Cities, Art, Media.

Herring, S. C. (2002). Computer-mediated communication on the Internet. Annual review of information science and technology, 36(1), 109168.

Hiltz, S. R., \& Turoff, M. (1993). The network nation: Human communication via computer. Mit Press. 
Ivanov, A.V. (2017). Destructive strategies in social networks and the philosophy of antiimmigration. Activities of law enforcement agencies to counter extremism and terrorism: materials of the all-Russian round table (Kazan, November 30, 2017). - Kazan- 45-47.

Ivanov, A.V. (2017). Portrait of a neo-racist in the coordinate system "friend-foe" in social networks. Kazan pedagogical magazine, 5, 153157 .

Jagatic, T. N., Johnson, N. A., Jakobsson, M., \& Menczer, F. (2007). Social phishing. Communications of the ACM, 50(10), 94-100.

Jean, B. (1981). Simulacres et simulation. Paris, Galilée.

Kardaras, D., Karakostas, B., \& Papathanassiou, E. (2003). The potential of virtual communities in the insurance industry in the UK and Greece. International Journal of Information Management, 23(1), 41-53.

King, I. (2010, April). Introduction to social computing. In International Conference on Database Systems for Advanced Applications (pp. 482-484). Springer, Berlin, Heidelberg.

Kiselev, A. A. (2007). Political participation in the Internet: an abstract. dissertations. Krasnodar.

KOLLOCK, P. (1999). The economics of online cooperation. In M. A. Smith \& P.

KOLLOCK (Eds.), Communities in cyberspace, London: Routledge.

KYRNIN, J. (2003). Building online communities. [Online]. 2003. Available www: http://webdesign.about.com/library/weekly/aa11 298.htm? once $=$ true $\&$ rnk $=$ r2\&terms $=$ onli.

LaPadula, T., Miles, J., \& Enrico, O. S. E. (2020). Re-imagining personal and organizational polices as sources of radical change: perspectives from a teaching artist, organization, and city. Arts Education Policy Review, 1-7.
Lazer, D., Pentland, A., Adamic, L., Aral, S., Barabasi, A.L., Brewer, D., Christakis, N., Contractor, N., Fowler, J., Gutmann, M., Jebara, T., King, G., Macy, M., Roy, D., Van Alstyne, M. (2009). Life in the network: the coming age of computational social science. Science, 323(5915).

Lenhart, A., Madden, M. (2007). Teens, privacy, \& online social networks. Pew Internet and American Life Project Report. Retrieved July 30,: http://www.pewinternet.org/pdfs/PIP_Teens_Priv acy_SNS_Report_Final.pdf.

Matthew N. O., Sarhan M. Musa. (2019). "Social Networking" Published in International Journal of Trend in Scientific Research and Development, (ijtsrd), ISSN: 2456- 6470, Volume-3, 2019. url:http://www.ijtsrd.com/papers/ijtsrd216 57.pdf.

McLuhan, M., \& MCLUHAN, M. A. (1994). Understanding media: The extensions of man. MIT press.

Nalani, A., Yoshikawa, H., \& Godfrey, E. B. (2021). Theorizing Organizational Learning to Enhance Youth-Adult Partnerships in CommunityBased Youth Serving Organizations. American Journal of Community Psychology.

Pfaffenberger, B. (1992). Social anthropology of technology. Annual review of Anthropology, 21(1), 491-516.

Rice-Lively, M. L. (1994). Wired warp and woof: An ethnographic study of a networking class. Internet Research.

Ridings, C. M., Gefen, D., \& Arinze, B. (2002). Some antecedents and effects of trust in virtual communities. The journal of strategic information systems, 11(3-4), 271-295.

Romm, C., Pliskin, N., \& Clarke, R. (1997). Virtual communities and society: toward an integrative three phase model. International journal of information management, 17(4), 261-270.

Smith, M.A., \& Kollock, P. (2002). Communities in cyberspace. London: Routledge. 1999.

Stutzman, F. (2006). An evaluation of identitysharing behavior in social network communities. Journal of the International Digital Media and Arts Association, 3(1), 10-18. 
Tosun, L. P., \& Lajunen, T. (2010). Does Internet use reflect your personality? Relationship between Eysenck's personality dimensions and Internet use. Computers in Human Behavior, 26(2), 162-167.

Tosun, L. P. (2012). Motives for Facebook use and expressing "true self" on the Internet. Computers in human behavior, 28(4), 1510-1517. The Russian sociological encyclopedia. Moscow: Norma-Infra, (1998). - P. 476.

Tönnies, F., \& Heberle, R. (1965). Einführung in die Soziologie.

Virtual communities and low-tech tools: lessons learned at the World Bank. [Online], Available www:http://ww.worldbank.prg/ks/k

practice_stories_virtual.html.

Ward, K. J. (1999). Cyber-ethnography and the emergence of the virtually new community. Journal of Information technology, 14(1), 95105.

Ventura Ccasa, B. (2021). Uso de los programas virtuales por los estudiantes del $\mathrm{V}$ ciclo en las instituciones educativas primarias de la provincia de Azángaro 2019

Williams, M. (2000). Virtually criminal: Discourse, deviance and anxiety within virtual communities. International Review of Law, Computers \& Technology, 14(1), 95-104.

Wellman, B. (1997). An electronic group is virtually a social network. Culture of the Internet, 4, 179-205. 